\title{
KONTEKSTUALISASI METODOLOGI MISIOLOGI PAULUS DALAM DUNIA KONTEMPORER
}

\author{
Yohanes Hasiholan Tampubolon \\ Jaringan Pemuda Kristen Hijau
}

\begin{abstract}
This article will explain the contextualization of methodology in Paul's missiology in the contemporary world. Paul's methodology can not be separated from Paul's theology. Therefore, this article will also discuss Paul's theological concepts of justification, salvation, reconciliation, etc. The article will begin with events in Damascus when he met Christ. The incident became the beginning of his call to preach the good news to other nations. Preaching the good news by Paul is preaching salvation from sin and come alive. Good news in Paul's mission is not limited to preaching the gospel of salvation, but also living the gospel in daily life.
\end{abstract}

Key Words: Paul, methodology, missiology, good news, salvation, contextualization

\begin{abstract}
Abstrak
Artikel ini akan menjelaskan mengenai kontekstualisasi metodologi dalam misiologi Paulus dalam dunia kontemporer. Metodologi Paulus tidak bisa dipisahkan dengan teologi Paulus. Oleh karena itu, dalam tulisan inipun akan membahas juga mengenai konsep teologis Paulus mengenai pembenaran, keselamatan, rekonsiliasi, dsb. Artikel akan dimulai dengan peristiwa di Damaskus ketika ia berjumpa dengan Kristus. Peristiwa tersebut menjadi awal panggilannya memberitakan Injil kabar baik kepada bangsa-bangsa lain. Memberitakan kabar baik oleh Paulus adalah memberitakan keselamatan dari dosa dan menjadi hidup. Kabar baik dalam Misi Paulus tidak sebatas memberitakan Injil keselamatan, namun juga menghidupi Injil tersebut dalam keseharian.
\end{abstract}

Kata kunci: Paulus, metodologi, misiologi, Injil, keselamatan, kontekstualisasi. 


\section{PENDAHULUAN}

David Bosch menuliskan di dalam buku Transformasi Misi Kristen bahwa untuk mengeksplorasi misiologi Paulus, perlu dimulai dari Paulus mengalami pertobatan dan panggilannya di Damaskus. ${ }^{1}$ Namun, mengenai peristiwa di Damaskus sendiri terjadi perdebatan di antara para ahli, apakah Paulus mengalami pertobatan atau panggilan khusus? Menurut beberapa ahli seperti Kristen Stendahl, peristiwa di Damaskus bukanlah momen pertobatan Paulus, karena Paulus tidak mengubah agamanya, Paulus tetap melayani Allah yang sama, perbedaannya, Ia menerima panggilan khusus dari Yesus Kristus. ${ }^{2}$ Melihat berbagai pandangan mengenai peristiwa di damaskus mengenai Paulus, penulis artikel ini akan merelevansikannya di dunia kontemporer.

Dalam menjalankan misi Kristen seringkali misi terjebak sebatas memeritakan Injil keselamatan. Injil tersebutpun lebih menekankan mengenai janji surga bagi yang percaya dan ancaman neraka bagi yang menolak. Artikel ini akan melihat sisi berbeda dengan melihat kepada sosok Paulus.

Penulis sendiri di dalam artikel ini memaparkan bahwa Paulus mengalami

\footnotetext{
${ }^{1}$ David Bosch, Transformasi Misi Kristen (Jakarta: Gunung Mulia, 1991), 127.

${ }^{2}$ Kristen Stendahl, Paul Among the Jews and Gentiles (Philadelphia: Fortress, 1973), 199-215.
}

pertobatan sekaligus panggilan. Di dalam artikel ini pertama-tama akan menjelaskan mengenai panggilan Paulus dan pertemuannya dengan Kristus yang mengubah seorang penganiaya jemaat menjadi murid Yesus. Kemudian, penulis menjelaskan mengenai metodologi dalam misiologi Paulus. Misi Paulus sendiri terbagi dua: kepada orang Yahudi dan nonYahudi (Rm. 1:16-17; Gal. 1:15-17). Artikel ini akan lebih terpusat pada bagian kedua, kepada orang non-Yahudi. Misi Paulus sebagai orang Kristen Yahudi kepada orang non-Yahudi kemudian diterapkan dalam konteks saat ini yakni, keterlibatan orang Kristen dengan penganut agama lain.

\section{METODOLOGI PENELITIAN}

Dalam meneliti artikel ini, penulis menggunakan metodologi penelitian melalui studi pustaka.

\section{ANALISIS DAN HASIL PENELITIAN}

$\underline{\text { Panggilan dan Pertobatan Paulus: Paulus }}$ $\underline{\text { sebagai Murid Kristus }}$

Paulus adalah seorang Yahudi seperti kedua belas murid Yesus yang lain, tetapi Paulus paling diingat sebagai missionaris kepada bangsa-bangsa lain. $^{3}$ Paulus

${ }^{3}$ D. L. Robert, Christian Mission: How Christianity Became a World Religion (Malden: Wiley-Blackwell, 2009), 12. 
memiliki panggilan dan ditugaskan oleh Kristus sebagai rasul bagi bangsa-bangsa non-Yahudi. Bruce Corley yang sepermikiran dengan Stendahlpun berpendapat bahwa peristiwa di Damaskus adalah mengenai panggilan khusus Paulus menjadi rasul bagi bangsa-bangsa lain dibandingkan dengan pertobatannya. ${ }^{4}$ Bosch pernah memberi tanggapan mengenai pandangan tersebut, "Stendahl, Corley and others go too far by regarding what hap-pened to Paul exclusively in terms of a call". 5 Jika melihat catatan Lukas mengenai pertemuan dramatis dengan Kristus (Kis. 19:1-19), tulisan Paulus dalam surat-suratnya (Gal. 1:11-17; Flp. 3:2-11; Rm. 7:13-25), tidak mudak melihat peristiwa tersebut hanya sebatas panggilan. Namun, Paulus sendiri tidak menjelaskan secara eksplisit mengenai pengalamannya di Damaskus adalah peristiwa pertobatan.

Beverly Gaventa membedakan antara pergantian (alternation), konversi dan transformasi. Gaventa menuliskan:

"alternation is a relatively limited form of change that develops from one's previous behavior, while conversion signifies a radical change in which past affiliations are rejected for new commitment, and

${ }^{4}$ Corley, "Paul's Conversion-Then and Now." The Road From Damascus: The Impact of Paul's Conversion on His Life, Thought and Ministry, ed. R.N. Longen-necker. 1-13 (Grand Rapids: Eerdmans, 1997), 3. 128. transformation represents a radical change of new cognition, which reinterprets or transforms the past without totally rejecting past" 6 .

Pergantian mengenai perubahan tidak menyeluruh dari perilaku sebelumnya, konversi adalah perubahan radikal yang meninggalkan masa lalu demi komitmen yang baru dan transformasi bersifat perubahan radikal secara kognitif, yang menafsirkan masa lalu atau mengubah masa lalu tanpa sepenuhnya menolak masa lalu. Stendahl sendiri menjelaskan bahwa yang terjadi pada Paulus adalah peristiwa pergantian, pandangan tersebut menganggap perubahan Paulus sebatas perubahan agama. Sedangkan pandangan konversi dan transformasi menjelaskan bahwa perubahan yang terjadi pada Paulus terdapat pada aspek perilaku dan kognitif.

Jika melihat dari kata Yunani mengenai pertobatan (metanoia), maka perubahan yang terjadi dimulai dari akal budi. ${ }^{7}$ Perjumpaan Paulus dengan Kristus dapat dikatan sebagai perubahan yang dimulai dari akal budi, seperti yang dituliskan oleh Paulus dalam 2 Korintus 4:6 “...Ia yang membuat terangNya bercahaya

${ }^{6}$ Beverly Gaventa, From Darkness to Light: Aspects of Conversion in the New Testament, Overtures to Biblical Theolog (Philadelphia: Fortress, 1986), 10-14.

${ }^{7}$ Joel B. Green, Conversion in Luke-Acts: Divine Action, Human Cognition, and thePeople of God (Grand Rapids: Baker Academic, 2015), 38-39. 
di dalam hati kita, supaya kita beroleh terang dari pengetahuan tentang kemuliaan ALlah yang nampak pada wajah Kristus.”. Pertobatan Paulus tidak hanya sampai aspek kognitif, namun, ia juga membaharui seluruh aspek dalam hidupnya secara menyeluruh, sehingga ia bertindak sesuai dengan panggilan ALlah dalam hidupnya untuk menjalankan misi bagi bangsabangsa lain. Jika melihat masa lalunya sebagai penganiaya orang-orang percaya, maka panggilan tersebut hanya bisa disebut sebagai anugrah Allah banginya (Kis. 8:3; Gal. 1:13-14), Ia pun dipilih menjadi Rasul sekalipun tidak pernah hidup berdampingan dengan Yesus seperi kedua belas murid Yesus yang lain (Gal. 1:15-16). Melihat berbagai sumber tersebut, pertobatan Paulus tidak bisa dikatakan sebatas perubahan agama, perubahannya mencakup aspek kognitif dan juga perilaku secara radikal atau konversi dan transformasi.

Perubahan yang dialami Paulus tidak sebatas satu meomen di Damaskus ketika ia bertemu dengan Kristus, perubahan yang dialami Paulus merupakan perjalanan transformasi sepanjang hidup yang disebut oleh joel Green sebagai transformation of habitus. ${ }^{8}$ Sedangkan konversi Paulus adalah perubahan radikal terdahulu (perilaku lama yang kejam dan buta rohani)

\footnotetext{
${ }^{8}$ Joel Green, ibid, 62.
}

kepada radikal yang kemudian (di dalam terang dan komitmen untuk memberitakan Injil kepada angsa-bangsa lain). Namun, perubahan radikal yang kemudian tersebut tidak sepenuhnya menolak agamanya yang lama (Yahudi), yang Paulus lakukan adalah menafsirkan kembali apa yang dipercayainya di masa lalu:

\footnotetext{
"As a consequence of his encounter with Christ, Paul proclaimed Christ as 'the end of the law, for everyone who has faith (Rom. 10:4), at the same time, as "the Lord of grace" who calls into the missionary service of the gospel of justification, and whose Torah corresponds eschatologically to Jewish Torah (Gal. 6:2)."9
}

Paulus melihat Yesus sebagai penggenapan dari yang telah dijanjikan Allah di Perjanjian Lama. Paulus menjembatani kepercayaannya yang dahulu dan imannya kepada Kristus. Seluruh ajaran tersebut di dalam kitab-kitab tulisan Paulus dimulai dari peristiwa di Damaskus dimana Paulus melihat Yesus (1 Kor. 9:1) dan Lukas menyebutnya sebagai cahaya memancar dari langit (Kis. 9:3). Peristiwa tersebut dapat disebut sebagai Christophany, yang mengawali Paulus untuk berpaling kepada Kristus dan menjadi pemberita injil bagi bangsa-bangsa lain. Panggilan tersebut berasal dari Firman

\footnotetext{
${ }^{9}$ Lapide \& Peter Stuhlmacher, Paul Rabbi and Apostle (Minneapolis: Augsburg, 1984), 24.
} 
Tuhan kepada Ananias: :Pergilah, sebab orang ini adalah alat pilihan bagi-Ku untuk memberitakan nama-Ku kepada bangsabangsa lain..." (Kis. 9:15).

\section{Eksplorasi Singkat Teologi Paulus}

Gaventa menuliskan dalam sebuah artikel, bahwa misiologi Paulus didasari atas penebusan Allah atas seluruh ciptaan (dunia dan manusia). ${ }^{10}$ Misi Allah adalah menyelamatkan ciptaan dari kuasa dosa dan kematian sehingga dapat memuji Allah dalam ciptaan yang baru baik secara individu dan keutuhan ciptaan. Di dalam kitab Galatia. 4:4-6 terlihat misi Allah yang dijelaskan oleh Paulus didasari atas pengutusan Yesus Kristus ke dalam dunia, menebus dan mengadopsi manusia sebagai anak-anakNya. Di dalam Kolose 1:20-22 kemudian menjelaskan bahwa di dalam Yesuslah Allah mendamaikan persekutuan dengan yang ada di bumi (seluruh kosmos dan antropos) berdasarkan kematian dan kebangkitan Yesus Kristus. ${ }^{11}$

Misi Allah menurut Paulus bersifat universal dan tidak bisa dilihat sebatas keselamatan individu-individu, selain itu, misi Allah tidak hanya bagi keselamatan manusia namun juga memiliki dimensi

\footnotetext{
${ }^{10}$ Beverly Gaventa, Apocalyptic Paul: Cosmos and Anthropos in Romans 5-8 (Waco:Baylor University Press, 2013).

${ }^{11}$ Michael Gorman, Becoming the Gospel: Paul, Participation and Mission (Grand Rapids: Eerdmans, 2009), 24.
}

kosmik. Michael Gorman menganjurkan untuk melihat misi dalam teologi Paulus tidak bisa dilihat dari kacamata individualitas "barat", tetapi perlu melihat dari kacamata keutuhan ciptaan secara holistik, baik itu antropos dan kosmos. ${ }^{12}$

Misi Paulus juga tidak dapat terlepas dari dimensi apokaliptik. Beberapa teolog Perjanjian Barupun ada yang menyebut Paulus sebagai teolog apokaliptik. Dalam Perjanjian baru, kata apocalypses dimaknai sebagai keyakinan di dalam kematian dan kebangkitan Yesus Kristus, telah menyingkapkan era baru melalui kemenangan Allah (1 Kor. 15). Kebangkitan Yesus Kristus sebagai awal dari zaman dan ciptaan yang baru (2 Kor. 5:17). Ini yang disebut sebagai eskatologi yang sedang berlangsung. Beverly Gaventa menuliskan bahwa pandangan eskatologi Paulus bukanlah suatu yang harus diantisipasi di masa depan yang jauh, karena keselamatan itu sedang terjadi di masa sekarang. ${ }^{13}$ Teolog sering menyebut sebagai fenomena "overlap" dua zaman. Seorang teolog dari kalangan Baptis evangelikal di Inggris, N. T. Wright, melihat pandangan Paulus mengenai ciptaan yang baru didasarkan pada

\footnotetext{
${ }^{12}$ Michael Gorman, Ibid, 24.

${ }^{13}$ Beverly Gaventa, Our Mother Saint Paul (Louisville: John Knox Press, 2007), 81.
} 
penyatuan antara surga di masa depan dan bumi pada saat ini. ${ }^{14}$ Ciptaan baru yang ada di bumi masih mengalami rasa sakit, pergumulan akan dosa, ketidakadilan, dsb., namun, ciptaan baru memiliki harapan dalam penebusan akhir di masa yang akan datang yang akan mengubah semuanya (Rm. 8:17-39).

Paulus melihat kita hidup di antara ketegangan yang sudah (already) dan yang belum (not yet). Di masa "antara" tersebut kita diselamatkan dengan harapan ( $\mathrm{Rm}$. 8:24). Jika membaca wahyu apokaliptik Paulus, maka, akan disuguhi mengenai harapan dalam kemenangan Yesus Kristus yang akan datang. Iman berakar pada kebangkitan Kristus (1 Kor. 15:14-15) dan pengharapan akan datang (Rm. 15:13), sehingga tugas manusia di saat ini adalah memberdayakan iman di masa "antara" yang sudah dan yang belum. Kehidupan di di masa tersebut harus terwujud dalam partisipasi dengan misi Allah demi tranfomasi dunia. Jadi, keselamatan bukan sekadar sesuatu yang diharapkan di masa yang akan datang, tetapi ada peran serta dalam mewartakan Injil dan menghidupinya.

\section{Misi Partisipatif}

Memproklamasikan Injil (1 Kor. 9:16-17) dan menghidupinya (1 Kor. 5:21) adalah inti dari misi partisipatif Paulus di masa "antara". Mewartakan Injil berkaitan dengan tugas secara verbal, sedangkan menghidupinya sebagai identitas misionalnya. Keduanya tidak dapat terpisahkan dalam pelayanan paulus.

\footnotetext{
"Karena jika aku memberitakan Injil, aku tidak mempunyai alasan untuk memegahkan diri. Sebab itu adalah keharusan bagiku. Celakalah aku, jika aku tidak memberitakan Injil. Kalau andaikata aku melakukannya menurut kehendakku sendiri, memang aku berhak menerima upah. Tetapi karena aku melakukannya bukan menurut kehendakku sendiri, pemberitaan itu adalah tugas penyelenggaraan yang ditanggungkan kepadaku."15
}

Pekerjaan proklamasi Injil bukanlah masalah beban pribadi, namun karena panggilan tugas "paksaan” dari kasih Allah, yang telah dibebankan sebagai tanggung jawab yang menggembirakan. Sukacita menjadi kekuatan pendorong menjalankan misi Paulus.

Pentingnya misi Partisipatif Paulus juga dapat dilihat dari perspektif babtisan dan perjamuan. Menurut Keck, dipabtis dan untuk merayakan perjamuan (mengingat

\footnotetext{
${ }^{15} 1$ Korintus 9:16-17.
}

\footnotetext{
${ }^{14}$ N. T. Wright, Paul and the Faithfulness of God (Minneapolis: Fortress, 2013).
} 
kematian dan mengantisipasi kedatangan Yesus) merupakan inti dari misi Paulus demi Injil keselamatan dan pemerintahan yang akan datang. ${ }^{16}$

Paulus melihat babtisan sebagai undangan kematiannya bersama Kristus (Gal. 2:20), bangkit kemudian hidup baru bersamaNya(1 Kor. 15) dan memasuki misi Kristus di dalam dunia. ${ }^{17}$ Kematian dan kebangkitan Kristus tidak bisa hanya dilihat sebagai sebuah peristiwa masa lalu yang menghasilkan manfaat bagi yang percaya di saat ini, tetapi orang percaya perlu turut mengambil bagian di dalamnya. Peristiwa tersebut bukanlah suatu yang transenden di masa lalu, demikian juga mengenai keselamatan, bukanlah suatu yang transenden di masa yang akan datang, namun itu semua perlu dialami melalui partisipasi memberitakan Injil keselamatan.

Di sisi perjamuan, Paulus melihat sebagai koinonia, persatuan dalam Kristus dalam tubuh dan darahNya (1 Kor. 11:2329), namun bukan berarti persekutuan internal tanpa ekspresi ke luar di masyarakat. ${ }^{18}$ Bahasa Paulus mengenai koinonia dalam sakramen sebagai partisipasi dalam misi Kristus dengan membagikan kasih bagi yang menderita

${ }^{16}$ L. E. Keck, Paul and His Letters (Philadelphia: Fortress, 1979), 77.

${ }^{17}$ Michael Gorman, Becoming the Gospel: Paul, Participation and Mission (Grand Rapids: Eerdmans, 2015), 27.

${ }^{18}$ Ibid, 30. dan kedamaian di tengah masyarakat. ${ }^{19}$ Beberapa teolog memakai istilah Injil rekonsiliasi sebagai bentuk partisipasi dalam menjalankan misi Allah. Paulus memproklamasikan Injil dan juga melakukan rekonsiliasi antara orang-orang Yahudi dan non Yahudi.

Selain untuk memproklamasikan Injil keselamatan dan rekonsiliasi, tujuan misi Paulus juga untuk menghidupi Injil tersebut (1 Kor. 11:1). Sebelumnya, perlu melihat pengertian pembenaran yang dimaksudkan Paulus. Para ahli seringkali melihat pembenaran Allah (dikaiosyne theou) menjadi dua aspek yang saling terkait, aspek forensik dan transformatif. Jika melihat teks dalam Rm. 1:16-17, frasa melalui iman kepada iman menunjukkan pembenaran yang bersifat forensik. Pembenaran tersebut bukan atas jasa manusia, namun sepenuhnya tindakan kasih karunia Allah melalui iman (Rm.3:20-25). Namun, ada juga yang berpandangan pembenaran juga berdimensi transformatif, dalam artian, pembenaran tersebut terjadi terus menerus mengubah kita menjadi serupa dengan Kristus. $^{20}$ Namun, dalam dalam pandangan lain melihat hal tersebut termasuk dalam aspek

${ }^{19} \mathrm{Ibid}, 31$.

${ }^{20}$ Michael Bird, The Saving Righteousness of God: Studies in Paul, Justification and the NewPerspective (Milton Keynes: Paternoster, 2007), 6. 
pengudusan progresif. Dalam dimensi transformatif tersebutlah misi dilakukan. Misi imatio Christi tidak hanya melihat misi sebagai suatu yang harus diproklamasikan tetapi juga dipraktikkan atau dikerjakan. Paulus tidak hanya memproklamasikan Injil tentang apa yang dilakukan Kristus, tetapi juga mempraktekkan apa yang dihidupi Yesus.

\section{Metodologi Misi Paulus Kepada orang-}

\section{Orang Non Israel}

Jika melihat misi yang dilakukan oleh paulus, banyak ahli misiologi memandang Paulus cenderung menggunakan misi model konsentrasi dibandingkan difusi (J. M. Terry, J.B. Green, R. Allen, dsb). Melalui model konsentrasi, metodologi berfokus pada komunikasi lintas budaya dan penanaman gereja yang dilakukan para misionaris, metode ini perlu upaya kontekstualisasi agar Injil tepat sasaran. ${ }^{21}$ Kontekstualisasi di sini berkaitan dengan masalah hermeneutis.

Dengan menggunakan metode konsentrasi, Paulus terbatas pada daerah tertentu dan orang-orang tertentu. Karena Ia mengabarkan Injil kepada orang-orang non Israel, maka ia berjalan dari Timur ke Barat menyisir kota-kota Helenis, seperti Efesus. Filipi, Tesalonika, Galatia dan Korintus. ${ }^{22}$

${ }^{21}$ John Terry, "Paul and Indigenous Missions." In Paul's Missionary Methods: In His Time and Ours (Downers Grove: InterVarsity Press, 2012), 170.
Tujuannya tidak sebatas pula hanya memberitakan Injil pembenaran, rekonsiliasi dan persekutuan di dalam Kristus, tetapi juga menanam gereja di kota-kota tersebut sehigga Injil seperti garam yang dapat meresap dan menjadi cahaya bagi dunia di sekitarnya.

Melalui metode konsentrasi, Paulus tidak sekadar menabur benih keselamatan, tetapi juga sampai pada menuai tuaian. Untuk mencapainya, Paulus melakukan perjalanan dari kota ke kota, berteman dengan penduduk setempat, memberitakan Injil keselamatan, menanam gereja-gereja lokal, di beberapa kota ia hanya beberapa minggu atau bulan, ia tidak pernah tinggal lebih dari tiga tahun di kota manapun selama perjalanan misinya. ${ }^{23}$ Kemudian, Paulus menunjuk orang-orang Kristen yang telah bertobat sebagai penatua di gereja yang ia tanam. Paulus menanam dan membiarkan gereja tersebut mandiri. Dalam Kisah Para Rasul 14:23, Lukas menjelaskan bahwa Paulus dan barnabas menunjuk para penatua di setiap gereja setempat melalui doa, puasa dan komitmen kepada Tuhan. Tetapi tidak berarti juga Paulus membiarkan mereka, sesekali juga Paulus berkunjunga dan menulis surat secara pribadi dan pastoral berkala. Di

\footnotetext{
${ }^{22}$ Ibid, 162.

${ }^{23}$ Ibid, 161.
} 
dalam Kisah Para Rasul 14:26-28 terlihat Paulus mempertahankan relasi yang kuat dengan gereja-gereja lokalnya di antara orang-orang non Yahudi. Tentunya Paulus tidak ingin benih pelayanannya mati, tetapi untuk bertumbuh melalui pelayanan para penatua dan oleh kuasa Roh Kudus.

Metode misi yang dipraktekkan paulus selanjutnya adalah pelayanan tim. Dalam pelayanan misi yang pertama ke Antiokhia, Paulus bekerja dengan Barnabas (Kis. 13:1-3), dalam perjalanan misi yang kedua di Asia Kecil, Paulus ditemani Silas, Timotius dan Lukas (18:22-23). Di perjalanan misi yang ketiga, ia ditemani oleh sejumlah perwakilan gereja-gereja yang telah dia tanam (20:4).

Ketiga, Paulus menggunakan metode yang disebut oleh Dean Flemming sebagai metode konstruktif dan korektif Paulus ${ }^{24}$ metode ini terlihat ketika Paulus di Antena (Kis. 17:16-34). Paulus memiliki panggilan memberitakan Injil kepada bangsa-bangsa non Yahudi, dan Atena adalah tempat yang strategis untuk menjalankan misi tersebut. atena merupakan tempat populasi besar orang beragama non Yahudi, disana merupakan pusat keagamaan dan pendidikan mereka, di sana pula mereka menggunakan Yunani yang juga sebagai bahasa perdagangan internasional. Paulus

\footnotetext{
${ }^{24}$ Dean Flemming, Contextualization in the New Testament: Pattern for Theology andMission (Downers Grove: InterVarsity Press, 2005), 76.
}

adalah orang Yahudi yang berbahasa Yunani (Kis. 21:39), Ia tentunya akrab dengan bahasa dan kebiasaan Yunani, yang memungkinkan untuk terlibat dengan caracara yang strategis dengan para penyembah berhala.

Isi Injil yang diproklamirkan Paulus dapat dibagi menjadi lima poin. 1) Allah sebagai pencipta alam semesta (17:24a), 2) Allah sebagai penopang kehidupan yang fana $(17: 25), 3)$ Allah sebagai penguasa semua bangsa (17:24b), 4) Allah sebagai "Bapak" semua manusia (17:28-29), 5) Tuhan sebagai hakim dunia $(17: 31) .^{25}$ Kelima poin ini mencerminkan wahyu umum Allah.

Sebelum memberitakan Injil, Paulus memuji orang-orang Atena: "Hai orangorang Atena, aku lihat, bahwa dalam segala hal kamu sangat beribadah kepada dewadewa" (17:22). Orang-orang Atena bisa disebut sebagai orang-orang yang religius dan saleh. Contoh lain orang bukan yahudi yang saleh adalah Kornelius (Kis. 10), Titius Yustus (Kis. 18:7) dan Lidia (16:14). Paulus melakukan pendekatan konstruktif, Ia tidak menolak pandangan dunia orangorang Athena, Paulus menggunakan pandangan dunia mereka sebagai dasar dialog. ${ }^{26}$ Paulus tidak memperkenalkan "dewa" yang sama sekali asing kepada

\footnotetext{
${ }^{25} \mathrm{Ibid}, 78$.

${ }^{26} \mathrm{Ibid}, 83$.
} 
orang-orang Athena, namun ia memperkenalkan Allah yang sudah dihormati di altar dengan tulisan "untuk Allah yang tidak dikenal". Allah tersebut tidak hanya tinggal bagian dunia tertentu dan perlu dilayani karena Ia tidak kekurangan (17:22-28). Allah tersebut memerintahkan agar orang-orang bertobat karena akan datang hari penghakiman, di mana Yesus yang telah memberikan bukti melalui kebangkitannya, akan menjadi hakim atas mereka (17:30-31). Pauluspun melakukan pendekatan korektif dalam memberitakan Injil kebangkitan, yang juga merupakan panggilan untuk pertobatan.

Melalui pendekatan dialog yang korektif, Paulus menyatakan kekeliruan penyembahan berhala (17:16) dan memanggil orang-orang untuk bertobat. Meskipun merasa sedih dengan penyembahan berhala, Paulus tidak langsung mengutuk mereka, melainkan ia menyampaikan pesannya dengan kata-kata yang penuh semangat. ${ }^{27}$ Paulus termotivasi oleh Injil untuk memenangkan orang-orang bukan Yahudi bagi Kristus (1 Kor. 9:2023). Para petobat baru seperti Dionisius, anggota majelis Areopagus, Damaris dan orang-orang atena lainnya melalui pendekatan dialog kontruktif dan korektif (17:34). $\underline{\text { Kontekstualisasi Misi Paulus dalam Dunia }}$ Kontemporer

Kepada jemaat Korintus Paulus menuliskan: "Jadilah pengikutku, sama seperti aku juga menjadi pengikut Kristus" (1 Kor. 11:1). Orang-orang Kristen saat inipun juga perlu meniru teladan Paulus dalam menjalankan misinya. Artikel ini akan menyarankan beberapa cara yang dapat dilakukan. Tentunya meniru bukan dalam hal perjalanan yang dilakukannya yang diperkirakan hingga 10.000 mil demi misinya, tetapi mengenai metodologi dan pemikiran misinya bagi dunia kontemporer.

Pertemuan Paulus dengan Yesus dan menjadi awal panggilannya. Mungkin sebagian besar orang saat ini tidak mengalami kejadian yang serupa pengalaman Paulus, namun, tanggapannya terhadap panggilan dari Yesus dan motivasi dalam menjalankan panggilan tersebut dapat ditiru. Motivasi misional Paulus didasari atas sukacita dan kasih (2 Kor. 5:14). Kasih pula yang "memaksa" yesus sendiri datang ke dunia, menjadi saksi sampai Ia mati di kayu salib. Kasih pula yang memaksa Paulus untuk menjadi saksi Kristus hingga ia mati di penggal di bawah pemerintahan Nero tahun 64 M. Kasih tersebut pula yang menjadi pendorong partisipasi orang percaya saat ini dalam menjalankan misi Allah.

\footnotetext{
${ }^{27}$ Ibid, 82.
} 
Konsep misi Paulus untuk memberitakan Injil dan menghidupi Injil. Panggilan gereja adalah memberitakan kabar baik.sayangnya, kabar baik tersebut dapat menjadi kabar buruk bagi orang kepercayaan lain melalui" ancaman" neraka. Kabar baik yang Paulus beritakan bukan hanya mengenai tentang pergi ke sorga, tetapi juga tentang menyelamatkan kita dari kuasa dosa dan maut kemudian menjadi hidup. ${ }^{28}$ Karena ini, Injil adalah kabar baik bagi semua orang. Injil adalah kabar baik karena kita dapat hidup melalui kematian Kristus. Paulus memberitakan kabar baik berpusat pada penebusan, seperti itu pula kita dapat memberitakan Injil kabar baik tentang penebusan Allah bagi orang berdosa dan kematian dan mengembalikan mereka dalam persekutuan dengan Allah.

Setelah itu orang yang telah menerima hadiah keselamatan tidak bisa hanya dilihat sebagai hadiah yang diterima, tetapi juga hadiah untuk mengubah hidup setiap orang untuk semakin serupa dengan Kristus. Inilah sifat transformatif dari keselamatan tersebut, Allah menyematkan manusia bukan dari sesuatu, namun untuk suatu perbuatan yang baik (Ef. 2:10). Misi Kristen tidak sebatas mempertobatkan orang dari agama-agama lain, tetapi, agar

${ }^{28}$ N. T. Wright, Simply Good News. Why the Gospel is News and What Makes It Good (New York: HarperCollins, 2015), 194. orang lain juga diperkaya oleh perilaku etis orang-orang Kristen.

"The church must be continually converted from her reconstructions of the gospel to its fullness. The Holy Spirit began the conversion of the church at Pentecost and has continued that conversion throughout the pilgrimage of God's people from the first century up to now. The conversion $f$ the church will be the continuing work of the Spirit until God completes the work begun in Jesus." 29

Keselamatan bukan hanya perasaan forensik tentang pembenaran, tetapi juga adalah proses pengudusan yang transformatif secara terus menerus. Dalam dunia yang majemuk di era globalisasi saat ini, perubahan etis dapat dibentuk dengan keterlibatan yang tulus dengan orang lain yang memiliki kepercayaan berbeda. Contoh dalam Alkitab mengenai kisah Petrus dan Kornelius (Kis. 10:1-48). Petrus sebagai contoh dari orang Kristen dan Kornelius adalah orang non Kristen. Kisah tersebut mengajarkan bahwa orang non Kristen bukanlah sebatas objek konversi semata, tetapi juga orang lain yang keramahtamahannya diberikan dan diterima.

Mengenai keselamatan sebagai rekonsialisi kepada orang-orang Yahudi

\footnotetext{
${ }^{29}$ Darrel Guder, The Continuing Conversion of the Church (Grand Rapids: Eerdmans, 2000), 206-207.
} 
dan non Yahudi. Di tengah dunia saat ini yang seringkali timbul konflik sosial mengatasnamakan agama, misi Kristen hadir untuk merekonsiliasi segala perbedaan yang ada. Rekonsiliasi Allah yang diberikan kepada orang percaya sebagai hadiah, sehingga panggilan misi kita pun menyaksikan rekonsiliasi ini dengan orang-orang yang berbeda lintas agama, budaya, dsb.

Paulus mengajarkan mengenai kontekstualisasi misi melalui dialognya kepada orang-orang Yunani di Athena. Paulus melaksanakan misi dengan mengkomunikasikan Injil secara komprehensif. Dia tidak memperkenalkan Allah yang sama sekali asing kepada orang Yunani, Paulus membuat "Allah yang tidak dikenal" diketahui oleh mereka dengan budaya lokal mereka (Kis. 17:23). Paulus memproklamirkan "Allah yang tidak dikenal" kepada orang Athena dengan pandangan dunia mereka (Kis. 17:23). Dalam tulisan-tulisannyapun, ia memberitakan Injil tidak hanya dari dalam budaya Yunani, tetapi juga merangkul pandangan dunia mereka untuk tulisantulisan teologisnya. ${ }^{30}$ Budaya Yunani tidak hanya membuka jalan bagi proklamasi Injil oleh Paulus, tetapi juga memperkaya konstruksi teologisnya. Melalui hal

${ }^{30}$ L. J. Johnson, Among the Gentiles: GrecoRoman Religion and Christianity (New Heaven: Yale University Press, 2009), 1. tersebut, orang-orang beragama lain tidak hanya sebatas objek misi, tetapi subjek dimana agama dan budayanya dapat membuka jalan bagi Injil dan juga memperkaya misiologi Kristen.

Yang terakhir adalah mengenai model penanaman gereja dan memperlengkapi para pemempin. Paulus tidak hanya mendirikan gereja dan membuat orang bertobat, dia juga terus memperhatikan dan memberi pengajaran demi pertumbuhan rohani mereka, kemurnian doktrinal dan transformasi etis mereka (Kis. 20:20-27). Bagi Paulus, gereja ada, oleh dan untuk misi Allah. Misi tersebut adalah proyek jangka panjang, berpartisipasi dalam misi Allah berarti memberitakan Injil keselamatan, memperlengkapi generasi-generasi baru dan masa depan, menghadirkan kedamaian bagi keutuhan ciptaan.

\section{KESIMPULAN}

Misiologi Paulus dan motivasinya dalam pekerjaan misionaris dimulai dengan pertemuan dramatisnya dengan Yesus Kristus. Kristus memanggilnya untuk menjadi misionaris bagi bangsa-bangsa lain. Teologi dan misi Paulus tidak hanya saling terkait sebagai teori dan praksis dan juga metodologi dan teologi, tetapi lebih 
dari itu, terologi Paulus adalah teologi misioner. Misiologi dan metode misi Paulus tidak dapat dipisahkan dan saling terhubung satu dengan yang lain.

Melalui misiologi dan metodologi misi Paulus mengajarkan bahwa teologi dan praktik misi harus berjalan bersama. Paulus adalah seorang teolog yang hebat, namun ia juga seorang misionaris. Melalui langkah hal tersebut dapat menarik dia ke dalam persekutuan yang lebih dalam bersama Kristus. Isi Injil (keselamatan, pembenaran, pennebusan, rekonsiliasi) perlu diaplikasikan dengan tepat dalam konteks kontemporer. Ketika kita diberikan anugrah dalam misi Allah, tugas kita bukan hanya memberitakan Injil keselamatan tetapi juga menghidupi Injil tersebut oleh kuasa Roh Kudus. Sehingga konsep misi tidak hanya "melakukan" (berpartisipasi dalam misi Allah), namun juga "menjadi" (mewujudkan sifat dari Allah kepada dunia).

\section{DAFTAR PUSTAKA}

Bird, Michael. 2009. The Saving Righteousness of God: Studies in Paul, Justification and the New Perspective. Milton Keynes: Paternoster.

Bosch, David. Transformasi Misi Kristen. Jakarta: Gunung Mulia.

Corley. 1997. "Paul's Conversion Then and Now." The Road From Damascus: The Impact of Paul's Conversion on His Life, Thought and Ministry, ed. R.N. Longen-necker. Grand Rapids: Eerdmans.
Flemming, Dean. 2005. Contextualization in the New Testament: Pattern for Theology and Mission. Downers Grove: InterVarsity Press.

Gaventa, Beverly. 1986. From Darkness to Light: Aspects of Conversion in the New Testament, Over-tures to Biblical Theolog .Philadelphia: Fortress.

Gaventa, Beverly. 2007. Our Mother Saint Paul. Louisville: John Knox Press.

Gaventa, Beverly. 2013. Apocalyptic Paul: Cosmos and Anthropos in Romans 58. Waco:Baylor University Press.

Gorman, Michael. 2015. Becoming the Gospel: Paul, Participation and Mission. Grand Rapids: Eerdmans.

Green, Joel B. 2015. Conversion in LukeActs: Divine Action, Human Cognition and the People of God. Grand Rapids: Baker Academic.

Guder, Darrel. 2000. The Continuing Conversion of the Church. Grand Rapids: Eerdmans.

Johnson, L. J. 2009. Among the Gentiles: Greco-Roman Religion and Christianity. New Heaven: Yale University Press.

Keck, L. E. 1979. Paul and His Letters. Philadelphia: Fortress.

Lapide. 1984. Paul Rabbi and Apostle. Minneapolis: Augsburg.

Robert, D. L. 2009. Christian Mission: How Christianity Became a World Religion. Malden: Wiley-Blackwell.

Stendahl, Kristen. 1973. Paul Among the Jews and Gentiles. Philadelphia: Fortress.

Terry, John. 2012. "Paul and Indigenous Missions." In Paul's Missionary Methods: In His Time and Ours. Downers Grove: InterVarsity Press.

Wright, N. T. 2013. Paul and the Faithfulness of God. Minneapolis: Fortress.

Wright, N. T. 2015. Simply Good News. Why the Gospel is News and What Makes It Good. New York: HarperCollins. 